\title{
DRUG RESISTANCE OF Pseudomonas spp. STRAINS ISOLATED FROM WATER RESERVOIRS AND SEWAGE TREATMENT PLANTS IN SZCZECIN
}

Student Research Group of Microbiology, Department of Immunology, Microbiology and Physiological Chemistry, West Pomeranian University of Technology in Szczecin

\begin{abstract}
The increasing resistance of bacteria to antibiotics has become a global problem. Among 12 most alarming bacteria, the WHO recognized carbapaneme-resistant Pseudomonas aeruginosa as resistant to carbapenems as a critical threat. These bacteria can cause nosocomial infections and are common in the natural environment, including in water used as bathing beach. For this reason, effective detection is necessary to prevent infections more effectively. The aim of this study was to determine antibiotic resistance of representatives of Pseudomonas genus isolated from the environment. Water from reservoirs located in Szczecin and an one sample of activated sludge were examined. Seven strains were selected for further studies. The basic physiological and biochemical characteristics of the genus Pseudomonas along with antibiotic resistance were examined. Mobility was assessed on Swarm Agar (Caiazza et al. 2005) and confirmed under phase-contrast microscope. Pseudomonas aeruginosa strain resistant to aztreonam was discovered among the isolates. Studies have shown that water reservoirs that are used for recreational purposes and water intake may be a reservoir of antibiotic resistant bacteria, including a carbapenem-resistant $P$. aeruginosa. Detection of these microorganisms could serve as a marker of water contamination that would prevent Pseudomonas infections and decrease the spreading of this bacteria among people and animals.
\end{abstract}

Key words: Pseudomonas spp., antimicrobial resistance, antibiotics.

\section{INTRODUCTION}

Bacteria from genus Pseudomonas are Gram- negative, aerobic, motile, rod-shaped microorganisms that can form a biofilm. Their natural life environment is soil, water, and plant surface among others (Palleroni 2015). On a solid medium Pseudomonas spp. form rough colonies that may have different characteristics, including pigment production and characteristic odour, depending on the species. Thanks to their adaptation capabilities these microorganisms can be used to protect the environment and bioremediation of soil (for example Pseudomonas putida) (Wasilkowski et al. 2012), although, they (especially $P$. aeruginosa) are also considered pathogens in animals and humans (Wolska et al. 2013). Because Pseudomonas can quickly acquire resistance to antibiotics, they should be taken into consideration in efforts aiming at preventing the spreading of antibiotic resistance. In these endeavours, farms and farm animals

Corresponding author: Marcjanna Wrzecińska, Student Research Group of Microbiology, Department of Immunology, Microbiology and Physiological Chemistry, West Pomeranian University of Technology in Szczecin, Piastów 45, 70-311 Szczecin, Poland, e-mail: marcjanna.wrzecinska07@onet.pl 
are particularly important, because animal production is considered one of the significant sources of antibiotic resistant strains, mainly due to the use of antibiotics as animal growth promoters or to prevent the spread of infections (Economou and Gousia 2015). Resistant pathogens can be transmitted from animals to humans and cause infections that are difficult to treat, resulting in higher mortality rates. Animal production waste can cause the release of resistant bacteria into the environment (Economou and Gousia 2015).

The drug resistant bacteria, including Pseudomonas spp., can have an impact on animal breeding. Microorganisms living in water reservoirs can be found in the digestive system of farm animals and their close environment. Furthermore, these microorganisms were found in the semen of animals, including rams, bulls, stallions and boars. It has been proven that these bacteria can have negative effects on sperm quality by reducing the motility or viability of sperm, and even cause changes in the morphology of sperm cells. As a consequence, this results in a reduction in reproductive efficiency and economic losses (Sepúlveda et al. 2014). The presence of Pseudomonas aeruginosa in semen for artificial insemination is a source of potential diseases and infections of the female reproductive system and may be the cause of embryonic death. To eliminate the etiological agent, antimicrobial preparations are usually included to the semen diluent. Bacteria isolated from semen are often resistant to generally used antibiotics (Sepúlveda et al. 2014). In humans $P$. aeruginosa is considered an opportunistic pathogen that can be particularly severe at burn units or in patients with cystic fibrosis. Because Pseudomonas are known for their adaptability and resistance to harsh environmental conditions, they can be possible source of antimicrobial resistance that can be transferred to other microorganisms (Panghal et al. 2015). For that reason, detection of pseudomonads and describing their drug resistance is necessary in drinking water used for people and animals.

The aim of the research was to isolate and determine the antibiotic resistance of Pseudomonas isolated from water and sludge samples taken from reservoirs located close to water intake system. The problem seems to be important for the discussion of the subject.

\section{MATERIAL AND METHODS}

\section{Water samples collection}

The samples of water from the water reservoirs located in Szczecin, including Głębokie

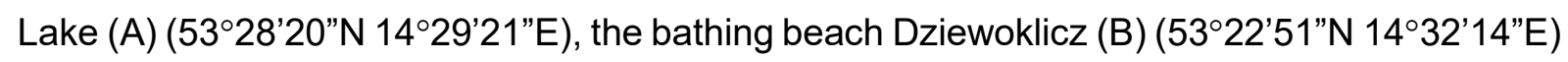
and the Odra River $(\mathrm{C})\left(53^{\circ} 24^{\prime} 11^{\prime \prime} \mathrm{N} 14^{\circ} 33^{\prime} 10^{\prime \prime} \mathrm{E}\right)$ (Fig. 1), as well as the activated sludge from the Sewage Treatment Plant have been sampled. All sampling points are located in high proximity to water intake installations. The samples of water have been taken one from each water reservoirs into sterilized containers (date of sampling: 15.10.2017). 


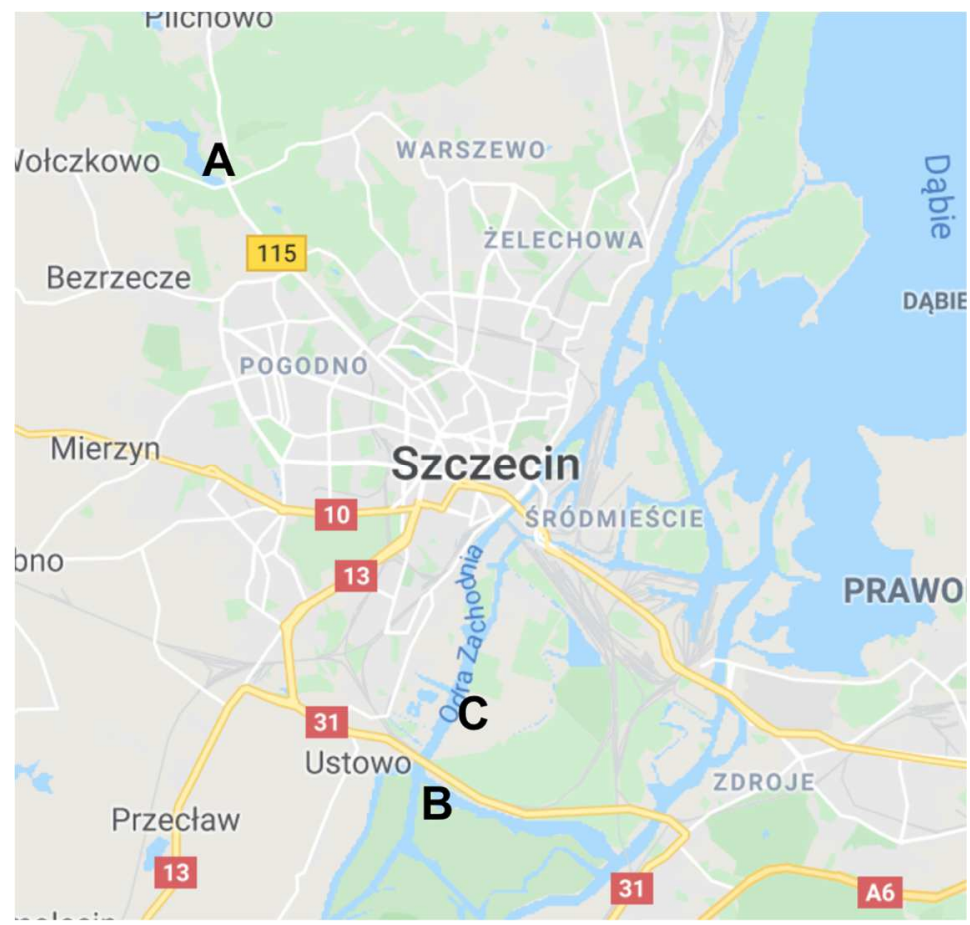

Fig. 1. Water sampling point

Source: Google maps.

\section{Isolation and characterization of microorganisms}

Tryptone Soy Agar (TSA) (BioMaxima, Poland) was used for the isolation of microorganisms from water samples.

The plates were inoculated with $100 \mu \mathrm{l}$ of samples diluted in ten-fold dilution method $\left(10^{-1}\right.$, $10^{-2}$ and $10^{-3}$ ). After evaluation of colony morphology and then they were cultured on the Cetrimid Media and chromogenic E. coli agar for more accurate diversification from the other Gram- negative microorganisms. Based on the growth of microorganisms on the Chromogenic Agar, strains showing characteristics other than commonly shown by Pseudomonas were discarded.

The oxidase test was carried out with a strip test (Oxoid, England), while catalase activity was tested with the hydrogen peroxide (3\% v/v).

MacConkey Agar (Scharlau, Spain) was used to defferentiate between Gram- positive and Gram- negative microorganisms. Other media, including Pseudomonas Agar for Fluorescein (BioMaxima, Poland) and Pseudomonas Agar for Pyocyanin (BioMaxima, Poland) were used in order to characterize the stains by their ability to produce pigments.

The biofilm formation abilities were using Microtiter Dish Biofilm Formation Assay according to O'Toole (2011). Plates were thrice washed with deionized water and fixated with methanol for $15 \mathrm{~min}$ at ambient temperature. Afterwards, plates were emptied, air dried, and biofilms were stained with crystal violet $(1 \% \mathrm{w} / \mathrm{v})$ for $15 \mathrm{~min}$ at room temperature. In the last stage, plates were washed with tap water and air dried. Biomass was decolorized with $200 \mu \mathrm{L}$ ethanol:acetone $(8: 2 \mathrm{v} / \mathrm{v})$ solution. Finally, $100 \mu \mathrm{L}$ of biomass was thrice pipetted and transferred to a new 96-well flat-bottom plate. Absorbance at $570 \mathrm{~nm}$ was read on microplate reader m200 PRO (Tecan, Männedorf, Switzerland). After obtained the results, the value and standard deviation were calculated. 
The motility was tested on three media - Swarm Agar (Caiazza, Shanks, and O'Toole 2005), modified TSB medium with glucose $(20 \%)$ and agar $(0.5 \%)$ and TSB with $\mathrm{MgSO}_{4}$, glucose $(20 \%)$ and agar $(0.5 \%)$. According to a modified methodology shown by Kearns (2010) was applied. The medium of Swarm Agar included 6 salts: $\mathrm{Na}_{2} \mathrm{HPO}_{4} \times 7 \mathrm{H}_{2} \mathrm{O}, \mathrm{KH}_{2} \mathrm{PO}_{4}, \mathrm{NaCl}, \mathrm{NH}_{4} \mathrm{Cl}$, $\mathrm{MgSO}_{4}, \mathrm{CaCl}_{2}$ as well as $0.2 \%$ glucose, $0.5 \%$ agar, $0.5 \%$ tryptone and water.

\section{Molecular identification of Pseudomonas aeruginosa}

The DNA isolation of the isolated strains was carried out in a freeze/thaw method by Osek et al. (2002). One colony of each isolate was suspended in $25 \mu \mathrm{H} \mathrm{H}_{2} \mathrm{O}_{d d}$ in an Eppendorf tube $(1.5 \mathrm{~mL})$. Afterwards, the tubes were heated to $100^{\circ} \mathrm{C}$ for 10 minutes and cooled in ice for 5 minutes. Then the samples were centrifuged and the supernatant containing genetic material was transferred into a new tube. In the next stage, Multiplex Polymerase Chain Reaction (PCR multiplex) was carried out in order to confirm that isolates belong to genus Pseudomonas and $P$. aeruginosa. The reaction mixture consisted of $5 \mu \mathrm{l}$ of which $1 \mu \mathrm{l}$ was received from DNA. The primers had the following sequences: PS1, 5'-ATGAACAA CGTTCTGAAATTCTCTGCT-3'; PS2, 5'-CTTGCGGCTGGCTTTTTCCAG-3'; PAL1, 5'-ATGGAAATGCTGAAATTCGGC-3'; and PAL2, 5'-CTTCTTCAGCTCGA CGCGACG-3'. After the reaction the samples were applied onto an agarose gel (Universal agarose PeqGold, Peglab) for electrophoresis and electrophoresis was performed and then the results were visualized. $P$. aeruginosa strain ATCC $^{\circledR} 27523^{\text {TM }}$ DNA was used as a reference. Detection used was based on the method presented by Vos et al. (1997). The amplicons obtained were electrophoretically separated at room temperature using $1.4 \%$ agarose gel with $0.003 \%$ ethidium bromide (EtBr, Merck) on PowerPac Basic (Bio- Rad) equipment. The separation was continued for 60 minutes at a constant voltage of $100 \mathrm{~V}(5 \mathrm{~V} / 1 \mathrm{~cm}$ of gel) in $1 \times$ TAE buffer (Tris- acetate- EDTA, Sigma) Electophoregrams were obtained by UV treatment of gel and then archiving using translluminator and system for documentation and analysis of gel- IG/LHR InGenius LHR (Syngene Bio Imaging) and GeneSnap software (Syngene).

\section{Antibiograms}

Antibiotic resistance was tested by disk diffusion method on Mueller-Hinton Agar medium (BioMaxima, Poland), according to EUCAST guidelines and TSA medium (BioMaxima, Poland). Following antibiotics were used: aztreonam (30 $\mu \mathrm{g})$, ceftasidim (30 $\mu \mathrm{g})$, ciprofloxacin $(5 \mu \mathrm{g})$, gentamicin $(10 \mu \mathrm{g})$ and meropenem $(10 \mu \mathrm{g})$. Plates were incubated for 24 hours at $37^{\circ} \mathrm{C}$. The test was repeated twice.

\section{RESULTS AND DISCUSSION}

\section{Biochemical characteristics of the microorganisms}

Seven isolates showed morphological and biochemical features of Pseudomonas spp. that are in accordance with literature data (Spencer and Brown 2015), included the ability to produce catalase and showing the cytochrome oxidase activity (Table 1). 
Table 1. Biochemical characteristics and swarming motility of Gram-negative rod-shaped isolates

\begin{tabular}{|c|c|c|c|c|c|c|c|}
\hline Caracteristic & $15 / 10 / G / A$ & 15/10/G/SP & 15/10/D/D & 15/10/W/ Ś2 & 24/10/TSA/M & $15 / 10 / D / 2$ & $24 / 10 / \mathrm{Ct} / 2$ \\
\hline Oxidase & + & + & + & + & - & - & - \\
\hline Catalase & + & + & + & + & + & - & + \\
\hline Swarming motility & - & + & + & - & + & - & + \\
\hline
\end{tabular}

The strains are named according to date, place of sampling and type of colony formed after the lawn cultured (for example 15/10/G/A - sampling on 15.10.2017 from Głębokie Lake, ' $A$ ' is an identification of colony on the plate, G/SP - isolated from Głębokie Lake, 'SP' is an identification name of colony on the plate, $D / D$ - isolated from Dziewoklicz Beach, ' $D$ ' it was a colony in the shape of a tree, W/Ś2 - isolated from Odra River nearby the Wyspa Pucka, 'Ś2' is an identification name of the second colony grown on the Agar for Fluorescein, TSA/M- 'M' refers to the colony size grown on the TSA medium plate, $\mathrm{D} / 2$ - second colony isolated from Dziewoklicz Beach, $\mathrm{Ct} / 2$ - the second colony obtained on Cetrimid Agar.

According to the Caiazza et al. (2005) the most and best visible results of Pseudomonas movement on agar were received on TSB medium with glucose $(20 \%)$ and agar $(0.5 \%)$ in D/D strain. The dendritic motion was obtained.

Tests using in this research have shown that in 4 cases of strains the results indicate the genus of Pseudomonas, because they are catalase- positive and oxidase-positive. The other 3 strains were not classified as Pseudomonas spp.

After performing a spectrophotometric sensing of the biofilm, results indicated the error bars presented in Fig. 2.

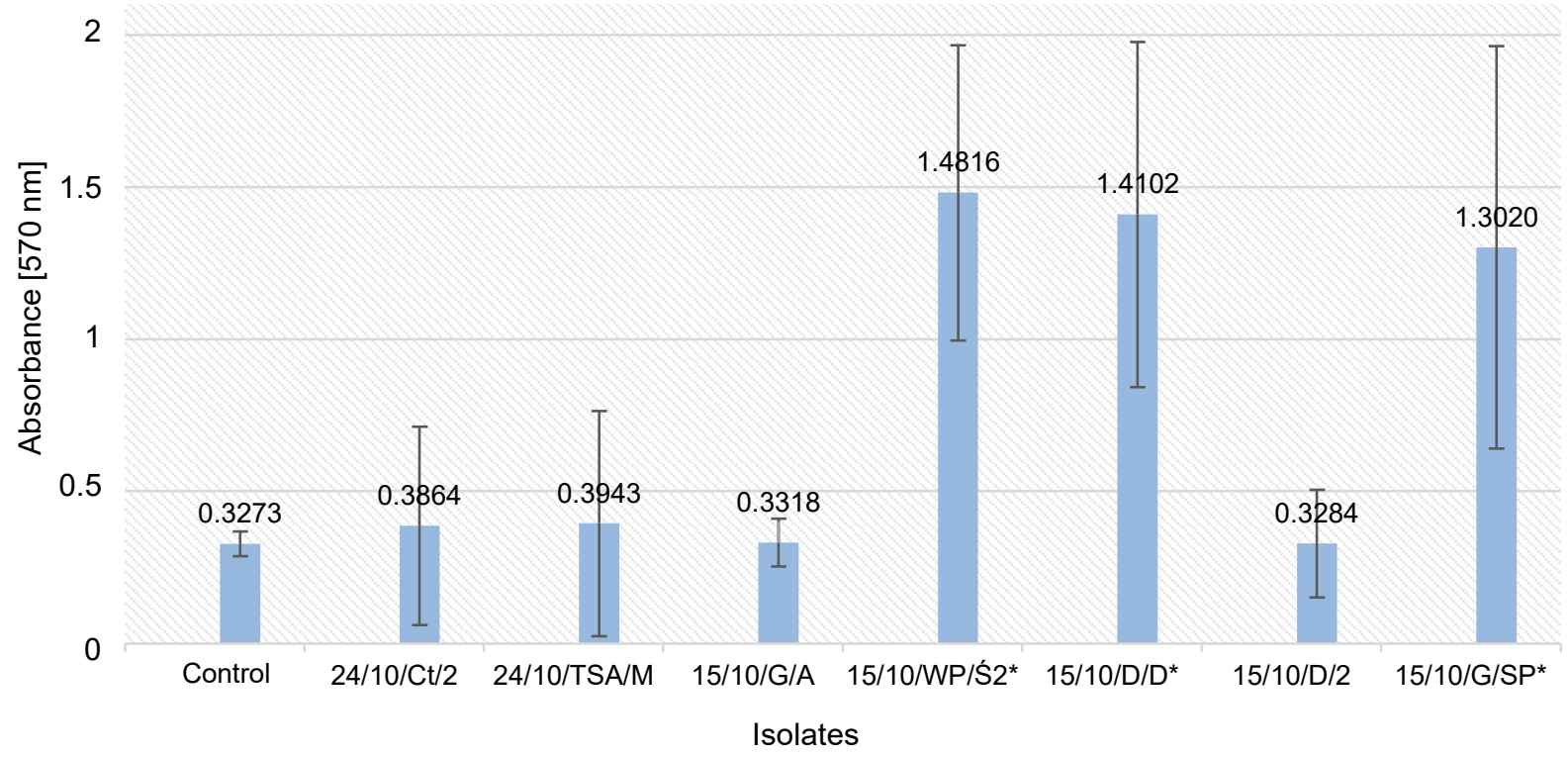

Fig. 2. Biofilm formation capability of isolated bacteria: * strains with good biofilming abilities; Non-adherent strains are characterized by $\mathrm{OD} \leq \mathrm{ODc}$ value, weakly adherent strains by $\mathrm{ODc}<\mathrm{OD} \leq 2 \times \mathrm{ODc}$, moderately adherent: $2 \times \mathrm{ODc}<\mathrm{OD} \leq 4 \times \mathrm{ODc}$, and strains with strong adherence are characterized by $4 \times$ ODc < OD. Pseudomonas usually express good biofilming abilities (Milivojevic et al. 2018). This feature was also confirmed within this study. The weakest biofilm ability was observed in D/2 $(0.3272<$ $0.3284 \leq 0.6546) \mathrm{G} / \mathrm{A}(0.3272<0.3318 \leq 0.6546)$, TSA/M $(0.3272<0.3943 \leq 0.6546)$ and $\mathrm{Ct} / 2(0.3272$ $<0.3864 \leq 0.6546)$ strains. On the other hand, the G/SP $(0.6546<1.3020 \leq 1.3092)$ strain was characterized by moderate biofilming abilities. In research the strongest ability production of biofilm was shown by D/D $(1.3092<1.4102)$ and WP/ŚP $(1.3092<1.4816)$ strains that were confirmed to be a representatives of Pseudomonas genus. The others did not show the ability to biofilming characteristic to Pseudomonas. 


\section{Isolation of the DNA and PCR multiplex}

PCR confirmed the presence of two strains of $P$. aeruginosa- G/SP, D/D and two other Pseudomonas - W/Ś2, G/A. One of the markers was Pseudomonas aeruginosa PA 27523 strain. The visualization of electrophoresis results confirmed that four microorganisms can belong to Pseudomonas genus (Aydemir et al. 1969). These results, combined with biochemical testing and culture methods gave a high probability that isolates can be described as Pseudomonas (Palleroni 2015).

Antibiograms were shown in the Table 2.

Table. 2. Antibiogram

\begin{tabular}{|c|c|c|c|c|c|c|c|}
\hline & $15 / 10 / \mathrm{G} / \mathrm{A}$ & 15/10/G/SP & 15/10/D/D & 15/10/W/ Ś2 & 24/10/TSA/M & $15 / 10 / \mathrm{D} / 2$ & $24 / 10 / \mathrm{Ct} / 2$ \\
\hline \multicolumn{8}{|c|}{ ANTIBIOGRAM 1 17/11/2017 on TSA } \\
\hline $\begin{array}{l}\text { ATM } 30 \\
\text { (aztreonam) }\end{array}$ & I & I & $\mathrm{R}$ & I & I & I & I \\
\hline $\begin{array}{l}\text { CAZ } 30 \\
\text { (ceftazydym) }\end{array}$ & $\mathrm{S}$ & S & $\mathrm{S}$ & $\mathrm{S}$ & $\mathrm{S}$ & S & $\mathrm{S}$ \\
\hline $\begin{array}{l}\text { CIP } 5 \\
\text { (ciprofloxacyna) }\end{array}$ & $\mathrm{S}$ & S & S & $\mathrm{S}$ & $\mathrm{S}$ & S & $\mathrm{S}$ \\
\hline $\begin{array}{l}\text { CN } 10 \\
\text { (gentamycyna) }\end{array}$ & $\mathrm{S}$ & S & S & $\mathrm{S}$ & $\mathrm{S}$ & S & $\mathrm{S}$ \\
\hline $\begin{array}{l}\text { MEM } 10 \\
\text { (meropenem) }\end{array}$ & $\mathrm{S}$ & S & $\mathrm{S}$ & S & $\mathrm{S}$ & S & S \\
\hline \multicolumn{8}{|c|}{ ANTIBIOGRAM 2 13/12/2017 on Mueller-Hinton } \\
\hline $\begin{array}{l}\text { ATM } 30 \\
\text { (aztreonam) }\end{array}$ & 1 & I & $\mathrm{R}$ & 1 & 1 & I & $\mathrm{S}$ \\
\hline $\begin{array}{l}\text { CAZ } 30 \\
\text { (ceftazydym) }\end{array}$ & S & $\mathrm{S}$ & $\mathrm{S}$ & $\mathrm{S}$ & S & S & $\mathrm{S}$ \\
\hline $\begin{array}{l}\text { CIP } 5 \\
\text { (ciprofloxacyna) }\end{array}$ & S & S & S & S & S & S & $\mathrm{S}$ \\
\hline $\begin{array}{l}\text { CN } 10 \\
\text { (gentamycyna) }\end{array}$ & S & $\mathrm{S}$ & S & $\mathrm{S}$ & S & S & $\mathrm{S}$ \\
\hline $\begin{array}{l}\text { MEM } 10 \\
\text { (meropenem) }\end{array}$ & S & S & $\mathrm{S}$ & S & $S$ & S & S \\
\hline
\end{tabular}

$\mathrm{S}$ - sensitive, I - intermediate, $\mathrm{R}$ - resistant.

The problem of drug resistance has been recognized by the WHO (Kollef et al. 2014). This organization published a list of 12 bacteria that create a particular risk to humans. Pseudomonas aeruginosa resistant to carbapenems has been listed as a critical threat among other. Pseudomonas aeruginosa is an opportunistic pathogen with the ability to cause hospital infections (Gabrysiak et al. 2016; Tacconelli 2017). Presence of such strains in water reservoirs should be a starting point for the discussion whether Pseudomonas should be included for water surveillance programmes.

Resistance to antibiotics is a global problem arriving from the inappropriate use of antibiotics, mostly in animal production (Grygorcewicz et al. 2017). Therefore, antibiotic resistant bacteria can be found around farms and crop fields. Such microorganisms can be found e.g. in slurry (Augustyniak et al. 2018). Antibiotics and microorganisms can be transferred into the ground, as well as into groundwater and other water reservoirs. Microorganisms that are exposed to antibiotics have developed resistance mechanisms that can spread through conjugation, horizontal gene transfer or transduction (Yen and Papin 2016). These mechanisms include for example production of enzymes splitting antibiotics, change in permeability of cell 
structures, or active removal of the substance from the cell (efflux pumps). Increasing drug resistance among bacteria result in the occurrence of multi-drug resistant (MDR) strains, which are resistant to 2 out of 3 primary antibiotics recommended for use against a given pathogen. MDR microorganisms are becoming a problem in the fight against infections with use the available antibiotics. Carbapenem-resistant Pseudomonas can be isolated from animals, which means that they can have contact with environmental strains (Haenni et al. 2017) such as one isolated in this study.

In these studies confirmed that water can be a reservoir of antibiotic resistant strains. The resistance was not common in the studied group, although the presence of $P$. aeruginosa resistant to aztreonam is particularly alarming because it may be multifactorial and lead to the creation of hypervirulence in Pseudomonas (Jorth et al. 2017). These bacteria present in drinking water can penetrate tissues through factorial elastase, which damages them. In this way microorganisms can be found in the semen of farm animals, which reduces the motility of sperm and thus the fertilisation capacity of animals with this semen (Sepúlveda et al. 2014). This is causing of economic losses. To prevent the emergence and spread of drug-resistant bacteria, use of antibiotics in animals should be restricted (Economou and Gousia 2015).

\section{CONCLUSION}

The outcome showed that the reservoirs including public bathing beach, can be a reservoir for Gram- negative microorganisms resistant to antibiotics, including carbapenems, such as Pseudomonas. The results of the research show the necessity to perform screening research in these areas, especially during periods of the highest activity of people and animals who may become carriers of drug-resistant opportunistic pathogens. It's necessary to detect those microorganisms and consider such procedures as a standard for water quality testing in order to prevent spreading of antimicrobial resistant strains, including carbapenem-resistant Pseudomonas spp. in the environment.

\section{REFERENCES}

Augustyniak A., Grygorcewicz B., Nawrotek P. 2018. Isolation of multidrug resistant coliforms and their bacteriophages from swine slurry. Turk. J. Vet. Anim. Sci. 42, 319-325.

Aydemir Ö., Aydemir Y., Özdemir M. 1969. The role of multiplex PCR test in identification of bacterial pathogens in lower respiratory tract infections. Pak. J. Med. Sci. 30(5), https://doi.org/10.12669/ pjms.305.5098, access: Jun 12, 2014.

Caiazza N.C., Shanks R.M.Q., O'Toole G.A. 2005. Rhamnolipids modulate swarming motility patterns of Pseudomonas aeruginosa. J. Bacteriol. 187, 7351-7361. https://doi.org/10.1128/JB.187.21.73517361.2005, access: Jun 30, 2015.

Economou V., Gousia P. 2015. Agriculture and food animals as a source of antimicrobial-resistant bacteria. Infe. Drug Resis. 8, 49-61, https://doi.org/10.2147/IDR.S55778, access: Apr 1, 2015.

Grygorcewicz B., Grudziński M., Wasak A., Augustyniak A., Pietruszka A., Nawrotek P. 2017. Bacteriophage-mediated reduction of Salmonella Enteritidis in swine slurry. Appl. Soil Ecol. 119, 179-182, https://doi.org/10.1016/j.apsoil.2017.06.020, access: Jul 7, 2017.

Haenni M., Bour M., Châtre P., Madec J.-Y., Plésiat P., Jeannot K. 2017. Resistance of animal strains of Pseudomonas aeruginosa to Carbapenems. Front. Microbiol. 8, 1847, https://doi.org/10.3389/ /fmicb.2017.01847, access: Jul 17, 2017. 
Jorth P., McLean K., Ratjen A., Secor P.R., Bautista G.E., Ravishankar S., Rezayat A., Garudathri J., Harrison J.J., Harwood R.A., Penewit K., Waalkes A., Singh P.K., Salipante S.J. 2017. evolved aztreonam resistance is multifactorial and can produce hypervirulence in Pseudomonas aeruginosa, https://doi.org/10.1128/mBio.00517-17, access: Oct 31, 2017.

Kearns D.B. 2010. A field guide to bacterial swarming motility. Nat. Rev. Microbiol. 8, 634-644, https://doi.org/10.1038/nrmicro2405, access: 2010 Sep.

Kollef M.H., Chastre J., Fagon J.-Y., François B., Niederman M.S., Rello J., Torres A., Vincent J.-L., Wunderink R.G., Go K.W., Rehm C. 2014. Global prospective epidemiologic and surveillance study of ventilator-associated pneumonia due to Pseudomonas aeruginosa. Crit. Care Med. 42, 2178-2187. https://doi.org/10.1097/CCM.0000000000000510, access: 2014 Oct.

Milivojevic D., Šumonja N., Medić S., Pavic A., Moric I., Vasiljevic B., Senerovic L., NikodinovicRunic J. 2018. Biofilm-forming ability and infection potential of Pseudomonas aeruginosa strains isolated from animals and humans. Pathogens and Disease, https://doi.org/10.1093/femspd/fty041, access: Apr 19, 2018.

O'Toole G.A. 2011. Microtiter dish biofilm formation assay. J. Vis. Exp. 2437, https://doi.org/10.3791/ /2437, http://www.jove.com/details.php?id=2437, Apr 19, 2018.

Palleroni N.J. 2015. Pseudomonas. Bergeys Man. Syst. Archaea Bact., Major Reference Works. https://doi.org/10.1002/9781118960608.gbm01210, access: Sep 14, 2015.

Panghal M., Singh K., Kadyan S., Chaudary U., Yadav J.P. 2015. The analysis of distribution of multidrug resistant Pseudomonas and Bacillus species from burn patients and burn ward environment. Burns 41, 812-819, https://doi.org/10.1016/j.burns.2014.10.014, access: Oct 9, 2015.

Sepúlveda L., Bussalleu E., Yeste M., Bonet S. 2014. Effects of different concentrations of Pseudomonas aeruginosa on boar sperm quality. Anim. Reprod. Sci. 150, 96-106, https://doi.org/ /10.1016/j.anireprosci.2014.09.001, access: Sep 17, 2014.

Spencer C., Brown H.A. 2015. Biochemical characterization of a Pseudomonas aeruginosa Phospholipase D. Biochemistry 54, 1208-1218, https://doi.org/10.1021/bi501291t, access: Feb 10, 2015.

Tacconelli E. 2017. Global priority list of antibiotic-resistant bacteria to guide research, discovery, and development of new antibiotics, https://www.who.int/medicines/publications/global-priority-listantibiotic-resistant-bacteria/en/, access: Feb 27, 2017.

Vos D.D., Lim A., Pirnay J.-P., Struelens M., Vandenvelde C., Duinslaeger L., Vanderkelen A., Cornelis P. 1997. Direct detection and identification of Pseudomonas aeruginosa in clinical samples such as skin biopsy specimens and expectorations by multiplex PCR based on two outer membrane lipoprotein genes, oprl and oprL. J. Clin. Microbiol. 35(5), 1295-1299.

Wasilkowski D., Swędzioł Ż., Mrozik A. 2012. The applicability of genetically modified microorganisms in bioremediation of contaminated environments. Chemik 66(8), 817-826.

Wolska K., Kot B., Piechota M., Frankowska A. 2013. Oporność Pseudomonas aeruginosa na antybiotyki. Post. Hig. Med. Dosw. 67, 1300-1311.

Yen P., Papin J. 2016. History of antibiotic adaptation influences microbial evolutionary dynamics during subsequent treatment (preprint). Systems Biol. 23, doi: http://dx.doi.org/10.1101/089334, access: Nov 23, 2016.

\section{LEKOOPORNOŚĆ SZCZEPÓW Pseudomonas spp. IZOLOWANYCH Z AKWENÓW ORAZ OCZYSZCZALNI ŚCIEKÓW NA TERENIE SZCZECINA}

Streszczenie. Rosnąca oporność bakterii na antybiotyki stała się światowym problemem. Wśród 12 bakterii stanowiących szczególne zagrożenie WHO wyróżniło szczepy Pseudomonas aeruginosa oporne na karbapenemy. Bakterie te mogą powodować zakażenia szpitalne, są powszechne w środowisku, w tym w wodzie używanej w kąpieliskach. $Z$ tego powodu skuteczne wykrywanie tych pałeczek jest konieczne, aby skuteczniej zapobiegać infekcjom. Celem badań 
było określenie antybiotykooporności przedstawicieli bakterii z rodzaju Pseudomonas wyizolowanych ze środowiska. Badaniom poddano próbki wody z akwenów znajdujących się na terenie Szczecina oraz próbkę osadu czynnego. Wyizolowano 7 szczepów. Zbadano podstawowe cechy fizjologiczne i biochemiczne Pseudomonas oraz oporność na antybiotyki. Mobilność oceniano na podłożu Swarm Agar (Caiazza et al. 2005) i potwierdzano kontrastowo pod mikroskopem. Wśród izolatów odkryto szczep Pseudomonas aueruginosa oporny na aztreonam. Badania wykazały, że zbiorniki wodne wykorzystywane do celów rekreacyjnych i poboru wody mogą być rezerwuarem bakterii opornych na antybiotyki, w tym opornej na karbapenem $P$. aeruginosa. Analiza obecności tych mikroorganizmów w przestrzeni publicznej umożliwiałaby ocenę skażenia wody, co zapobiegałoby zakażeniom Pseudomonas i zmniejszyłoby rozprzestrzenianie się tej bakterii wśród ludzi i zwierząt.

Słowa kluczowe: Pseudomonas spp., antybiotykooporność, antybiotyki. 
